\title{
Studi Analisis Peran Pesantren Sidogiri Dalam Pembentukan Karakter Kemandirian Ekonomi Masyarakat Perspektif Sosiologi
}

\author{
Dewi Masyitha ${ }^{1}$ \\ Alvan Fathony ${ }^{2}$
}

\begin{abstract}
Abstrak
Pesantren sebagai lembaga pendidikan sekaligus lembaga sosial memiliki peran yang strategis dalam membangun kemandirian masyarakat. Realitanya, masyarakat seringkali menyelepelekan peran pesantren tersebut, dengan menganggap bahwa pesantren hanya bisa melahirkan para pemikir ilmu-ilmu tradisional, agamawan dan/atau da'i. Anggapan tersebut dimentahkan oleh pesantren Sidogiri, dengan tidak hanya mengembangkan sistem pendidikan semata, tetapi juga mulai berkiprah di ranah pengembangan sistem ekonomi berbasis syari'ah. Berbagai cara dilakukan di antaranya memberikan pelatihan tentang ekonomi syari'ah baik kepada santri, para alumni maupun masyarakat di sekitar pesantren.
\end{abstract}

\section{Kata Kunci: Pesantren Sidogiri, Kemandirian, Ekonomi Masyarakat.}

\section{Pendahuluan}

Pesantren adalah salah satu jenis lembaga pendidikan yang secara historis cukup penting peranannya di Indonesia. Pesantren yang pada umumnya terletak di desa-desa atau pedalaman memiliki pengaruh yang cukup kuat dalam kehidupan masyarakat di sekelilingnya. Pesantren juga

\footnotetext{
${ }^{1}$ Dosen Prodi Hukum Ekonomi Syariah STAI AL-YASINI.

${ }^{2}$ Universitas Nurul Jadid Paiton Probolinggo
} 
merupakan lembaga sosial yang mewaliki “sub-culture” tersendiri dalam lingkungan masyarakat Indonesia ${ }^{3}$.

Mastuhu mendefinisikannya sebagai lembaga pendidikan tradisional Islam untuk memahami, menghayati dan mengamalkan ajaran Islam dengan menekankan pentingnya moral agama Islam sebagai pedoman hidup bermasyarakat sehari-hari ${ }^{4}$. Sesuai dengan fungsinya sebagai lembaga pendidikan, dakwah, sosial kemasyarakatan, keagamaan, bahkan lembaga perjuangan, unsur-unsur atau elemen-elemen yang dimiliki pesantren tentunya menjadi aspek pendukung yang kuat bagi kehidupan kultur pesantren hingga saat ini.

Makalah ini akan membahas bagaimanakah prinsip dasar Islam pesantren sidogiri dalam mengembangkan ekonomi Islam? Dimana prinsip dasar Islam tersebut sebagai acuan peranan pesantren Sidogiri dalam pembentukan karakter kemandirian ekonomi masyarakat. Kemudian prinsip Islam tersebut kita bandingkan dengan konsep Marx Weber terkait spirit kapitalis sehingga makalah ini akan menganalisa secara langsung kebenaran sosiologi profetik dibidang ekonomi Islam dan membuktikan pengembangan ekonomi Islam yang diperankan Pesantren Sidogiri ini mampu membentuk karakter kemandirian ekonomi masyarakat Islam.

\footnotetext{
${ }^{3}$ Prasojo, Sudjoko dkk, "laporan Hasil Penelitian Pesantren al-Falak dan Delapan Pesantren lain di Bogor" (Jakarta: 1974), hlm. 15.

${ }^{4}$ Mastuhu, Dinamika Sistem Pendidikan Pesantren ,(Jakarta: INIS, 1994), hlm. 6.
} 


\section{Sekilas Peran Pesantren}

Pesantren berasal dari kata "santri” dengan awalan pe dan akhiran an berarti tempat tinggal para santri ${ }^{5}$. Selain istilah pesantren ada beberapa istilah lain yang sering digunakan untuk menunjuk jenis lembaga pendidikan Islam yang kurang lebih memiliki ciri-ciri yang sama. Di Jawa termasuk Sunda dan Madura menggunakan istilah pondok atau pondok pesantren, sementara di Minangkabau menggunakan istilah surau, di Aceh rangkah meunasah. ${ }^{6}$ Apapun istilahnya jelas kesemuanya tersebut di atas berbeda atau bisa dibedakan dengan lembaga pendidikan milik kaum muslimin yang lain, yaitu madrasah dan sekolah dengan berbagai jenis dan jenjang yang ada.

Tujuan didirikannya pesantren pada dasarnya terbagi menjadi 1) tujuan khusus yaitu mempersiapkan para santri untuk menjadi orang alim dalam ilmu agama yang diajarkan oleh kiai yang bersangkutan dan mengamalkannya dalam kehidupan bermasyarakat, 2) tujuan umum yaitu membimbing anak didik agar menjadi manusia yang berkepribadian Islam yang sanggup mengamalkan ilmunya dan menjadi muballigh bagi masyarakatnya. ${ }^{7}$ melihat tujuan tersebut jelas bahwa pesantren merupakan lembaga yang berusaha mencetak insan yang bertafaquh fi ad-din, dan menyebarluaskan misi-misi Islam demi tegaknya nilai-nilai ajaran Islam.

${ }^{5}$ Zamakhsyari Dhofier, Tradisi Pesantren; Studi Tentang Pandangan Hidup Kiai (Jakarta: LP3ES, 1982), hlm. 18.

${ }^{6}$ M Dawam Raharjo, Dunia Pesantren dalam...hlm. 2.

${ }^{7}$ HM Arifin, Kapita Selekta Pendidikan (Jakarta: Bumi Aksara:1991), hlm. 248. 
M. Bahri Ghazali, mengklasifikasikan pesantren menjadi tiga kategori. Pengklasifikasian ini didasarkan pada sistem dan kurikulum yang digunakan. Pertama, pesantren tradisional, tipe ini merupakan pesantren yang menggunakan sistem dan kurikulum klasik. Model pengajaran yang digunakan pada pesantren tradisional bervariasi, sorogan, bandongan, dan wetonan. Pesantren tradisional banyak mengajarkan ilmu bahasa (nahwusharaf; ilmu gramatikal dan balaghah; sastra bahasa Arab), fiqh dan tasauf (moral).

Tipe kedua adalah pesantren modern. Istilah modern merujuk pada model pesantren yang memiliki lembaga pendidikan ala barat (sistem klasikal). Sistem dan kurikulum yang digunakannya pun agak sedikit berbeda dengan pesantren tradisional. Rujukan kitab yang digunakan oleh pesantren tradisional adalah kitab-kitab kuning yang disusun oleh para ulama pada masa keemasan Islam. Sedangkan rujukan kitab yang digunakan oleh pesantren modern adalah kitab-kitab kontemporer yang disusun oleh ulama saat ini. Penerapan sistem belajar klasikal (dengan pengelompokan kelas berdasarkan tingkatan umur dan kemapuan). Pesantren modern memiliki lembaga pendidikan formal yang dikelola secara profesional dibawah Depag ataupun Diknas. Dari pendidikan dasar hingga jenjang tinggi (SMA atau MA) dan bahkan beberapa diantaranya memiliki perguruan tinggi.

Tipe ketiga adalah pesantren komprehensif. Tipe ini merupakan gabungan dari sistem tradisional dan modern. Pesantren tipe ini menerapkan pendidikan dan pengajaran kitab kuning dengan metode 
sorogan, bandongan dan wetonan, namun juga secara reguler sistem sekolah konfensional dikembangkan. Lebih dari itu, pesantren tipe ini telah mengembangkan sistem pendidikan alternatif melalui kursus dan pelatihan. $^{8}$

Tipologi ini memberikan gambaran bahwa pesantren merupakan lembaga pendidikan yang telah lama berkembang dan telah melakukan ekselerasi dan inovasi dalam sistem pembelajaran dan kurikulum. Kenyataan demikian tentu didasarkan pada realitas bahwa pesantren sebagai lembaga sosial keagamaan dituntut untuk menghasilkan human capital yang tangguh.

Giddens dalam buku-bukunya memunculkan Nation-state and Violence, karena dua konsep itu menjadikan kapitalisme memberikan andil terbesar dalam kekeruhan dunia modern saat ini. Kapitalisme mendorong manusia untuk terus berkompetisi, sementara industrialisme merangsang manusia untuk berinovasi. Kompetisi mendorong untuk inovasi teknologi mengalami percepatan perkembangan akibat dukungan modal dari korporat-korporat raksasa. Para kapitalis tidak henti-hentinya menemukan produk-produk baru, demikian pula para teknolog. Dalam hal ini batasbatas teritorial negara (nation-state) tidak dihiraukan, demikian pula batasbatas kultur. Bahkan manusia sebagai individu juga tidak diperhitungkan.

\footnotetext{
${ }^{8}$ M. Bahri Ghazali, "Pesantren Berwawasan Lingkungan” (Jakarta: Prasasti,2003), hlm. 1415. Lihat juga Abdullah Syukri Zarkasyi, "Langkah Pengembangan Pesantren" dalam Rekonstruksi Pendidikan dan Tradisi Pesantren; Religiusitas Iptek (Yogyakarta: Fakultas Tarbiyah IAIN Sunan Kalijaga dan Pustaka Pelajar. 1998), hlm. 220.
} 
Yang penting adalah maju dan baru. Yang terakhir ini terkait erat dengan social reflexivity.

Manusia modern memang dapat mengambil keputusan sendiri. Ia menghadapi banyak informasi, tetapi ia bebas menyeleksi informasi mana yang ia butuhkan untuk pengambilan keputusan. Arus (tepatnya: banjir) informasi memang membuatnya bingung, namun harus mengambil keputusan. Individu sering dapat menolak sebuah informasi semata-mata ia tidak suka atau tidak cocok. Ambillah contoh di bidang pengobatan. Orang dapat memilih pengobatan cara Barat tetapi ia dapat juga memilih "pengobatan alternatif." Mengapa ia memilih yang satu dan tidak yang lain? Jawaban yang diperoleh sering berupa "tidak tahu".

Dalam bukunya The Consequences of Modernity (1990), Giddens memakai metafor "Juggernaut" (sebuah truk besar) yang lepas kendali. Metafor ini dengan tepat menggambarkan situasi dunia yang menakutkan. Ancaman perang, perusakan lingkungan, kekuasaan sewenang-wenang, penindasan kaum buruh. Ini semua berlangsung dalam suasana di mana tak ada lagi perlindungan yang lokal dari serbuan, tidak ada pegangan baku, dan semua orang merasa yakin akan pilihannya sendiri. Individualisme sedemikian tajamnya sehingga menghancurkan solidaritas sosial. Umat manusia kini berada dalam ancaman besar. Giddens memang bicara tentang "manufactured risk", dan masyarakat yang mengalaminya disebut "risk society". 
Pesantren dalam kerangka ini, justru mampu menghindari bentuk kekerasan dan akses negatif lain dari globalisasi. Globalisasi adalah neo kolonialisme karena membawa gerbong kapitalisme yang entah klasik atau yang telah diperbaharui, praktis bersendi Darwinisme. Memang bagus dan hebat untuk yang kuat dan pandai, yang kuasa dan yang tega, akan tetapi kita tidak boleh lupa bahwa Darwinisme berakar pada prinsip mengganyang yang lemah oleh yang kuat, the survivel of the fittest. Pesantren dalam kapasitas dan kemandiriannya sejauh ini dapat menghindari dari ekses ekonomi dan politik yang negatif.

Pesantren saat ini mungkin dapat dikategorikan sebagai satusatunya lembaga Civil Society yang mampu menjaga kemandirian pada negara, menyesuaikan diri dengan melakukan perubahan lewat detradisionalisasi tanpa harus meninggalkan tradisi atau Al-muhaafadzatu 'alaa qadiimis shaalih wal-akhdzu bil jadiidil ashlah (mempertahankan tradisi lama yang baik dan mengambil tradisi baru yang lebih baik). Dan mampu menghindari dari pop culture yang mewabah akibat dari globalisasi. Secara ekonomi, pesantren juga dapat menjaga kemandirian ekonomi, dengan sedapat mungkin menghidupi sendiri tanpa tergantung pada bantuan asing (luar negeri).

Salah satu contoh pesantren yang menjadi lembaga Civil Society yang mampu menjaga kemandirian pada negara adalah Pesantren Sidogiri Pasuruan dimana pesantren ini melakukan inovasi dan terobosan dalam sistem pembelajaran dan segi manajemennya juga yang turut bisa 
meninggalkan stigma bahwa pesantren itu kuno dan tempat yang menyeramkan.

Pondok pesantren (Ponpes) Sidogori Pasuruan terpilih menjadi pesantren terbaik. Banyak hal yang mempengaruhi terpilihnya pesantren ini menjadi salah satu pesantren terbaik di Indonesia, salah satu pertimbangannya adalah sebagai berikut:

a. Pesantren ini merupakan salah satu pesantren tertua di Indonesa yang masih eksis dan terus berkembang.

b. Di zaman modern ini, pesantren ini tetap berani mempertahankan sistem pendidikan salaf murni yang mengkaji ilmu agama, walaupun demikian hebatnya pesantren ini berhasil mempertahankan jumlah santri yang terbilang cukup banyak, yaitu sekitar puluhan ribu santri putra dan putri.

c. Terkenal sebagai pesantren yang berhasil mandiri secara finansial berkat berbagai bisnis yang dibangun oleh yayasan pesantren seperti waralaba minimarket (Mart) yang bernama Koperasi Sidogiri, lembaga keuangan yang bernama BMT (baitul Mal Wat Tamwil), serta masih banyak usaha lainnya.

Faktor-faktor penting lainnya yang menjadikan Ponpes Sidogori ini menjadi salah satu pesantren terbaik di Indonesia adalah karena komitmen para pengurus ponpes Sidogiri yang tetap mempertahankan sistem pendidikan Madrasah Diniyah (MD) sampai tingkat Ma'had Ali (Universitas) yang bernama Tarbiyatul Mu'alimin. Selain itu pesantren ini 
sering mengirim guru tugas ke berbagai daerah di Indonesia serta luasnya jaringan alumni pesantren ini ${ }^{9}$.

\section{Sosiologi Ekonomi Marx Weber}

\section{Semangat Kapitalisme}

Dalam esai etika protestan dan semangat kapitalisme, Weber menyebutkan agama adalah salah satu alasan utama perbedaan antara budaya barat dan timur. Ia mengaitkan efek pemikiran agama dalam kegiatan ekonomi, hubungan antara stratifikasi sosial dan pemikiran agama serta pembedaan karakteristik budaya barat. Tujuannya untuk menemukan alasan mengapa budaya barat dan timur berkembang dengan jalur yang berbeda. Weber kemudian menjelaskan temuanya terhadap dampak pemikiran agama puritan (protestan) memiliki pengaruh besar dalam perkembangan sistem ekonomi di Eropa dan Amerika Serikat, namun tentu saja ini ditopang dengan faktor lain diantaranya adalah rasionalitas terhadap upaya ilmiah, menggabungkan pengamatan dengan matematika, ilmu tentang pembelajaran dan yurisprudensi, sistematisasi terhadap administrasi pemerintahan dan usaha ekonomi. Studi agama menurut Weber semata hanyalah meneliti satu emansipasi dari pengaruh magi, yaitu pembebasan dari pesona. Hal ini menjadi sebuah kesimpulan yang dianggapnya sebagai aspek pembeda yang sangat penting dari budaya yang ada di barat.

${ }^{9} 10$ Pesantren Terbaik Di Indonesia - qolbunhadi.html 
Max Weber dengan baik mengaitkan antara Etika Protestan dan Semangat Kapitalis (Die Protestan Ethik Under Giest Des Kapitalis). Tesisnya tentang etika protestan mempengaruhi pertumbuhan ekonomi kapitalis. Ini sangat kontras dengan anggapan bahwa agama tidak dapat menggerakkan semangat kapitalisme. Studi Weber tentang bagaimana kaitan antara doktrin-doktrin agama yang bersifat puritan dengan faktafakta sosial terutama dalam perkembangan industri modern telah melahirkan corak dan ragam nilai, dimana nilai itu menjadi tolak ukur bagi perilaku individu.

Karya Weber tentang The Protestan Ethic and Spirit of Capitalism menunjukkan dengan baik keterkaitan doktrin agama dengan semangat kapitalisme. Etika protestan tumbuh subur di Eropa yang dikembangkan seorang yang bernama Calvin, saat itu muncul ajaran yang menyatakan seorang pada intinya sudah ditakdirkan untuk masuk surga atau neraka, untuk mengetahui apakah ia masuk surga atau neraka dapat diukur melalui keberhasilan kerjanya di dunia. Jika seseorang berhasil dalam kerjanya (sukses) maka hampir dapat dipastikan bahwa ia ditakdirkan menjadi penghuni surga, namun jika sebaliknya kalau di dunia ini selalu mengalami kegagalan maka dapat diperkirakan seorang itu ditakdirkan untuk masuk neraka.

Upaya untuk merebut kehidupan yang indah di dunia dengan "mengumpulkan" harta benda yang banyak (kekayaan) material, tidak hanya menjamin kebahagiaan dunia, tetapi juga sebagai media dalam mengatasi kecemasan. Etika Protestan dimaknai oleh Weber dengan kerja yang luwes, bersemangat, sungguh-sungguh, dan rela melepas 
imbalan materialnya. Dalam perkembangannya etika Protestan menjadi faktor utama bagi munculnya kapitalisme di Eropa dan ajaran Calvinisme ini menebar ke Amerika Serikat dan berpengaruh sangat kuat disana.

Weber mendefinisikan semangat kapitalisme sebagai bentuk kebiasaan yang sangat mendukung pengejaran rasionalitas terhadap keuntungan ekonomi. Semangat seperti itu telah menjadi kodrat manusia-manusia rasional, artinya pengejaran bagi kepentingankepentingan pribadi diutamakan daripada memikirkan kepentingan dan kebutuhan kolektif seperti yang dikehendaki oleh Kar Marx.

Islam pun sebenarnya berbicara tentang kaitan antara maknamakna doktrin dengan orientasi hidup yang bersifat rasional. Dalam salah satu ayat disebutkan bahwa setelah menyelesaikan ibadah shalat, diperintahkan untuk bertebaran di muka bumi ini dalam rangka mencari karunia Allah SWT. Namun dalam Islam ada mekanisme penyeimbangan yang digunakan untuk membatasi kepemilikan pribadi dengan kewajiban membayar zakat, infaq dan shadaqah.

Menurut Max Weber bahwa suatu cara hidup yang teradaptasi dengan baik memiliki ciri-ciri khusus kapitalisme yang dapat mendominasi yang lainnya merupakan kenyataan yang real ketika masamasa awal revolusi industri, ketika Weber hidup, kenyataan-kenyataan itu mejadi sesuatu yang benar-benar nyata dipraktekkan oleh manusia. Hidup harus dimulai di suatu tempat dan bukan dari individu yang terisolasi semata melainkan sebagai suatu cara hidup lazim bagi keseluruhan kelompok manusia. 
Volume 01 Nomor 01, Desember 2017

\section{Kerangka Berfikir Ekonomi Kapitalisme}

Sistem perekonomian kapitalisme adalah sistem perekonomian yang memberikan kebebasan secara penuh kepada setiap orang untuk melaksanakan kegiatan perekonomian ${ }^{10}$. Landasan filosofi yang digunakan dalam sistem ekonomi kapitalis adalah materialisme dan sekulerisme ${ }^{11}$. Pengertian manusia sebagai homo economicus atau economic man adalah manusia yang materalis hedeonis, sehingga ia selalu dianggap memiliki serakah atau rakus terhadap materi. Dalam perspektif materalisme hedonis murni, segala kegiatan manusia dilatar belakangi dan diorientasikan kepada segala sesuatu yang bersifat material. Manusia dianggap merasa bahagia jika segala kebutuhan materialnya terpenuhi secara melimpah. Pengertian kesejahteraan yang materialistik seperti ini sering kali menafikan atau paling tidak meminimalkan keterkaitannya dengan unsur-unsur spritual.

Disisi lain dari landasan filosofi kapitalisme adalah sekularisme. Yaitu memisahkan hal-hal yang bersifat spiritual dan material secara dikotomis. Segala sesuatu yang berkaitan dengan dunia merupakan urusan manusia itu sendiri sedangkan agama hanyalah mengurusi hubungan manusia dengan tuhannya saja. Maka, dalam sistem kapitalisme, norma dan etika menjadi barang langka yang sulit ditemukan.Untuk mengidentifikasi ideologi kapitalis.

\footnotetext{
${ }^{10}$ Nur Chamid, Jejak Langkah Sejarah Pemikiran Ekonomi Islam.( Yogyakarta : Pustaka Pelajar : 2010), hal : 366

${ }^{11}$ M Umer Chapra, Masa Depan Ilmu Ekonomi, ( Jakarta: Gema Insani Press, 2001 ), hal: 3
} 
Disini perlu dikemukakan mengenai ide-ide dari kapitalisme itu sendiri. Ada beberapa ide pokok yang dianggap menjadi gagasan terpenting dan paling mendasar dalam kapitalisme dewasa ini. Pertama, diakuinya hak milik perorangan secara luas, bahkan hampir tanpa batas. Kedua, diakui adanya motif ekonomi, mengejar keuntungan secara maksimal, pada semua individu. Ketiga, adanya kebebasan untuk berkompetisi antar individu, dalam rangka peningkatan status sosial ekonomi masing-masing. Keempat, adanya mekanisme pasar yang mengatur persaingan dan kebebasan tersebut ${ }^{12}$. Disamping itu, Umar Chapra mengemukakan tentang ciri yang menonjol dari kapitalisme ${ }^{13}$ :

1. Ia menganggap ekspansi kekayaan yang dipercepat dan produksi yang maksimal serta pemenuhan keinginan (want) menurut preferensi individual sebagai sangat esensial bagi kesejahteraan manusia.

2. Ia menganggap bahwa kebebasan individu yang tak terhambat dalam mengaktualisasikan kepentingan diri sendiri dan kepemilikan atau pengelolaan kekayaan pribadi sebagai sesuatu hal yang sangat penting bagi inisiatif individu.

3. Ia berasumsi bahwa inisiatif individual ditambah dengan pembuatan keputusan yang terdesentralisasi dalam suatu pasar kompetitif sebagai syarat utama untuk mewujudkan efesiensi optimum dalam alokasi sumber daya.

\footnotetext{
${ }^{12}$ Awalil Rizki dan Nasyith Majidi, Neo Liberalisme Mencengkram Indonesa, hal : 216

${ }^{13}$ M. Umer Chapra. Islam dan Tantangan Ekonomi, ( Jakarta: Gema Insani Press, 2000), hal: 18
} 
4. Ia tidak mengakui pentingnya peran pemerintah atau penilaian kolektif, baik dalam efesiensi alokatif maupun pemerataan ditribusi.

5. Ia mengklaim bahwa melayani kepentingan diri sendiri (self interest) oleh setiap individu secara otomatis melayani kepentingan sosial kolektif.

Kapitalisme memandang bahwa manusia adalah pemilik satusatunya terhadap harta yang diusahakan, tidak ada hak orang lain di dalamnya ${ }^{14}$. Konsep hak milik dalam kapitalisme sangat tak terbatas sehingga individualistis sangat ditonjolkan dalam kapitalisme ini. Kebebasan absolut ini merupakan sebuah rumusan yang dikemukakan oleh John Locke yang mengatakan bahwa manusia adalah miliknya sendiri. Bahkan John Locke menyatakan bahwa perolehan pribadi tanpa batas sesungguhnya sesuai dengan ajaran-ajaran injil maupun menurut akal sehat. Norma semacam ini mengakibatkan masyarkat lebih cenderung memikirkan kegiatan yang efektif dalam mencari harta. Sehingga dialiktika kehidupan kapitalis mendorong sikap yang mementingkan diri sendiri. Faktor pendukung kebebasan ini adalah ${ }^{15}$ :

1) Pandangan terhadap eksistensi individu sebagai pusat dunia dan tujuan yang akan diraih

2) Adanya tujuan untuk merealisasikan kekuasaan terbesar bagi kepentingan individu, dan pertimbangan bahwa kepentingan umum dinyatakan sebagai kumpulan kepentingan-kepentingan individu.

\footnotetext{
${ }^{14}$ Abdullah A. Husein At-tariqi, Ekonomi Islam, Prinsip, dasar dan Tujun, ( Yogyakarta: MIP, 2004 ), hal : 40

15 Abdullah A. Husein At-tariqi, Ekonomi Islam, hal : 40
} 
3) Urgensi kebebasan ekonomi tanpa batas dan perdagangan sempurna yang diharapkan akan memberikan jaminan kebutuhan para konsumen.

Motif mencari keuntungan merupakan ide lain dari kapitalisme. Sistem ekonomi kapitalis dipengaruhi oleh semangat mendapatkan keuntungan semaksimal mungkin dengan sumber daya yang terbatas. Usaha kapitalis ini didukung oleh nilai-nilai kebebasan untuk memenuhi kebutuhan. Dalam mendapatkan laba sebanyak-banyaknya tersebut, kadangkala sampai tidak memperdulikan etika dan moral karena ketatnya persaingan tersebut. Kebebasan yang ditawarkan kapitalis membawa konsekuensi persaingan atau kompetisi yang sangat ketat antar individu. Sehingga kompetisi ini berujung pada mekanisme pasar dalam menentukan harga.

Adam Smith adalah peletak dasar pemikiran kapitalisme yang menjelaskan bekerjanya mekanisme hukum pasar atas dasar dorongan kepentingan-kepentingan pribadi karena kompetisi dan kekuatan individualisme dalam menciptakan keteraturan ekonomi. Melaluinya, kapitalisme melakukan klasifikasi antara nilai guna dengan nilai tukar yang ada pada setiap komoditi. Ukuran riil dari nilai tukar komoditi, harus dilihat dari kondisi pertukaran, dimana 'ukuran riil' dari nilai komoditi adalah kuantitas dari kerja yang berada dalam barang-barang lain yang dapat dipertukarkan di pasar. 


\section{Sosiologi Ekonomi Islam}

Nasution mengemukakan sitem ekonomi Islam adalah suatu sistem ekonomi yang di dasarkan pada ajaran dan nilai- nilai Islam yang bersumber dari Al- Quran, Sunnah, Ijma, Qiyas atau sumber lainnya. Nilai-nilai sistem ekonomi Islam ini merupakan bagian integral dari keseluruhan ajaran Islam yang komprehensif. ${ }^{16}$

Islam telah mengatur kehidupan manusia dengam ketentuan ketentuan yang telah di syariahkan. Keberadaan aturan itu semata - mata untuk menunjukkan jalan bagi manusia dalam memperoleh kemulyaan. Perilaku orang muslim dalam bidang ekonomi selalu diorientasikan pada peningkatan keimanan, karena implementasi dari pemahaman islam akan membentuk kehidupan yang islami dalam masyarakat secara langsung. Sistem ekonomi islam di bangun berdasarkan atas sumber islam yakni Alquran dan Hadist ${ }^{17}$.

Secara konseptual terdapat perbedaan mendasar antara ekonomi konvensional dan ekonomi Islam dalam memandang manusia. Ekonomi konvensional mengasumsikan mansusia sebagai rational economic man, sedangkan ekonomi Islam hendak membentuk manusia yang berkarakter Islamic man ('ibadurrahman ). Islamic man dianggap perilakunya rasional jika konsisten dengan prinsip-prinsip Islam yang bertujuan untuk menciptakan masyarakat yang seimbang. Tauhidnya mendorong untuk

\footnotetext{
${ }^{16}$ Ismail Mawawi. Ekonomi Islam : Perspektif Teori, Sistem, dan Aspek Hukum, ( Surabaya, CV. Putra Media Nusantara, 2009), hal : 42

${ }^{17}$ Heri Sudarsono. Konsep Ekonomi Islam : Suatu Pengantar, ( Yogyakarta, Ekonisia, 2004), hal :105
} 
yakin, Allah lah yang berhak membuat rules untuk mengantarkan kesuksesan hidup $^{18}$.

Isalamic man dalam mengkonsumsi suatu barang tidaklah dilandasi hanya untuk mencari kepuasaan belaka. Namun lebih dari pada itu, seorang Islamic man akan lebih mempertimbangkan tentang status barang tersebut apakah halal atau haram dan cara mendapatkannya merugikan orang lain atau tidak. Merupakan pertimbangan-pertimbangan yang harus diperhitungkan oleh seorang Islamic man. Oleh karena itu, Islamic man tidak lah materialistik. Ia selalu memegang prinsip syari'ah yang selalu menekankan pentingnya berbuat kebajikan terhadap semua orang. Tolong menolong, peduli terhadap sesama merupakan diantara karakterisik Islamic man yang berkecimpung di dalam aktivitas perekonomian. Berbeda dengan kapitalisme yang mempunyai karakter materalistik sehingga kurang mengindahkan nilai-nilai etika.

\section{E. Dasar - dasar Ekonomi Islam}

Adapun dasar ekonomi Islam adalah sebagai berikut ${ }^{19}$ :

1. Ekonomi Islam ingin mencapai masyarakat yang berkehidupan sejahtera dunia dan akhirat.

2. Hak milik relative perorangan diakui sebagai usaha dan kerja secara halal dan digunakan secara halal juga.

3. Di larang menimbun harta benda dan menelantarkannya

\footnotetext{
${ }^{18}$ Nurcholis, "Perbedaan Mendasar Ekonomi Islam dan Ekonomi Konvensional",dalam Menjawab Keraguan dalam Berekonomi Syari'ah, ( Yogyakarta: Safira Insania Press, 2008 ), hal : 62

${ }^{19}$ M. Rusli Karim. Berbagai Aspek Ekonomi Islam, (Yogyakarta , PT. Tiara Wacana, 1992), hal : $61-62$
} 
4. Pada batas tertentu hak milik relatife dikenakan pajak

5. Perniagaan diperkenankan dan riba di larang

6. Tidak ada perbedaan suku dan keturunan dalam bekerja sama dan yang menjadi ukuran perbedaan hanyalah prestasi saja.

\section{F. Prinsip - Prinsip Ekonomi Islam}

Para ulama Islam telah menyepakati bahwa salah satu tujuan terpenting syari'ah adalah mengurangi kesulitan dan berusaha untuk menjadikan hidup setiap manusia menjadi nyaman. Adapun prinsip dasar sistem ekonomi islam adalah ${ }^{20}$ :

a. Kebebasan individu

b. Hak terhadap harta

c. Ketidaksamaan ekonomi dalam batas yang wajar

d. Jaminan sosial

e. Distribusi kekayaan

f. Larangan menumpuk kekayaan

g. Kesejahteraan individu dan masyarakat

Dalam ekonomi Islam, hukum hak milik individu adalah hak untuk memiliki, menimati dan memindah tangankan kekayaan yang diakui dan dipelihara oleh Islam, tetapi mereka mempunyai kewajiban moral untuk menyedekahkan hartanya, karena kekayaannya itu juga merupakan hak masyarakat bahkan hewan. Oleh karena itu, al-Qur'an tidak menginginkan harta kekayaan itu hanya berputar diantara orang-orang kaya saja. Dalam ajaran Islam, hak milik dikategorikan menjadi tiga, yaitu:

\footnotetext{
${ }^{20}$ Heri Sudarsono. Konsep Ekonomi Islam : Suatu Pengantar, hal :105
} 
a. Hak milik individual ( milkiyah fardhiyah / privat ownership )

b. Hak milik Umum atau publik ( milkiyah 'ammah / public ownership )

c. Hak milik negara ( Milkiyah daulah / state ownership ).

Dalam ekonomi Islam tujuan yang hendak dicapai adalah falah.

Oleh karenanya matrealisme atau keuntungan sebanyak-banyaknya tidaklah menjadi tujuan utama dari ekonomi Islam. Mencapai falah yakni kebahagiaan di dunia dan diakhirat merupakan rujukan utama bagi ekonomi Islam. Hal inilah yang dikatakan sebagai kesejahteraan hakiki.

Dalam ekonomi kapitalisme, kita kenal motif ekonomi untuk mendapatkan keuntungan sebanyak-banyaknya. Ini menandakan falsafah materalisme kapitalis yang orientasinya hanya diarahkan kepada hal-hal yang berbau materi belaka. Pada akhirnya motivasi dari semua itu hanyalah untuk memenuhi kepentingan dirinya sendiri dengan cara memaksimalkan kekayaan dan konsumsinya lewat cara apapun. Menurut Islam, manusia harus mengendalikan dan mengarahkan kehendaknya (want) sehingga dapat membawa maslahah dan bukan mudharat.. Sedangkan keperluan ( need ) muncul dari suatu pemikirtan atau identifikasi secara objektif atas berbgai sarana yang diperlaukan untuk mendapatkan manfaat bagi kehidupan. Keperluan diarahkan oleh rasionaliti normatif dan positif yaitu rasionalitas ajaran Islam, sehaingga bersifat terbatas dan terukur dalam kuantitas dan kualitas. Jadi, seorang muslim mengkonsumsi suatu barang atau jasa dalam rangka memenuhi keperluannya sehingga memperoleh manfaat yang setinggi-tingginya bagi kehidupannya. Hal ini merupakan asas dan tujuan dari syariat Islam itu sendiri yaitu maslahah al-ibad, ( 
kesejahteraan hakiki untuk manusia ), sekaligus sebagai cara untuk mendapatkan falah yang maksimum ${ }^{21}$.

Berkaitan dengan mekanisme pasar yang mengagungkan kebebasan individu. Islam dengan tegas menolak pandangan mengenai keagungan privat proverty, kepentingan investor, asceticism ( menghindari kehidupan duniawi ), economic egalitarianism maupun authoritarianism ( ekonomi terpimpin atau paham mematuhi seseorang atau badan secara mutlak). Dalam mekanisme pasar, sebenarnya Islam juga membolehkan mekanisme penentuan harga diserahkan ke pasar. Dan dalam hal ini pasar tidak mengharapkan adanya intervensi dari pihak manapun, tak terkecuali negara dengan otoritas penentuan harga atau privat sektor dengan kegiatan monopolistik ataupun lainnya.

Guna memberi pemahaman komperhensif penulis memetakan perbedaan antara ekonomi Islam dan kapitalis sebagaimana berikut:

\begin{tabular}{|l|l|l|}
\hline NO & \multicolumn{1}{|c|}{ ISLAM } & \multicolumn{1}{c|}{ KAPITALIS } \\
\hline 1 & $\begin{array}{l}\text { Sumbernya dari Al-Qur'an, As Sunnah } \\
\text { dan Ijtihad }\end{array}$ & $\begin{array}{l}\text { Sumbernya dari pikiran dan pengalaman } \\
\text { manusia }\end{array}$ \\
\hline 2 & Berpandangan dunia holistik & Berpandangan dunia sekuler \\
\hline 3 & $\begin{array}{l}\text { Kepemilikan individu terhadap kapital } \\
\text { adalah nisbi }\end{array}$ & $\begin{array}{l}\text { Kepemilikan individu terhadap kapital } \\
\text { adalah mutlak }\end{array}$ \\
\hline 4 & $\begin{array}{l}\text { Mekanisme pasar bekerja menuurut } \\
\text { maslahat }\end{array}$ & $\begin{array}{l}\text { Mekanisme pasar dibiarkan bekerja } \\
\text { sendiri }\end{array}$ \\
\hline
\end{tabular}

\footnotetext{
${ }^{21}$ http://www.paltangerangkota.go.id/index.php?option=com_content\&view=article\&id=288: menelusuri-sistem-ekonomi-islam-dan-sistem-ekonomi-kapitalis-sebuah-tinjauansingkat\&catid=3:artikel-makalah\&Itemid=49, 22 mei 2012.
} 


\begin{tabular}{|l|l|l|}
\hline 5 & $\begin{array}{l}\text { Kompetisi pasar dikontrol oleh diktum } \\
\text { syariah }\end{array}$ & $\begin{array}{l}\text { Kompetisi pasar bersifat bebas dan } \\
\text { melahirkan monopoli-survival of the } \\
\text { fittest }\end{array}$ \\
\hline 6 & $\begin{array}{l}\text { Kesejahteraan fungsi dari jasmani, ruhani, } \\
\text { dan akal }\end{array}$ & $\begin{array}{l}\text { Kesejahteraan ditentukan oleh faktor- } \\
\text { faktor materi jasadiah }\end{array}$ \\
\hline 7 & $\begin{array}{l}\text { Profit motive diakui lewat cara-cara yang } \\
\text { halal }\end{array}$ & $\begin{array}{l}\text { Profit motive diakiu tanpa ada batasan } \\
\text { normatif }\end{array}$ \\
\hline 8 & $\begin{array}{l}\text { Mengakui free enterprise dalam koridor } \\
\text { yang halal }\end{array}$ & $\begin{array}{l}\text { Mengakui free enterprise tanpa batasan } \\
\text { apapun }\end{array}$ \\
\hline 9 & $\begin{array}{l}\text { Pemerintah aktif sebagai pengawas, } \\
\text { pengontrol, dan wasit yang adil }\end{array}$ & $\begin{array}{l}\text { Pemerintah sebagai penonton pasif yang } \\
\text { netral }\end{array}$ \\
\hline 10 & $\begin{array}{l}\text { Mekanisme redistribusi pendapatan sangat } \\
\text { menonjol }\end{array}$ & $\begin{array}{l}\text { Tidak dikenal, hanya bila ada tekanan } \\
\text { dari berbagai kelompok }\end{array}$ \\
\hline
\end{tabular}

Pada kesimpulannya Ekonomi Islam mempersembahkan kepada umat manusia adalah sebagai berikut

1. Kemakmuran dan kesejahteraan sejati (falah dan hasanah)

2. Keadilan (al-adalah)

3. Persaudaraan (al-ukhuwah)

4. Distribusi pendapatan dan kekayaan yang merata

5. Menjaga agar individual interest harmonis dengan sosial interest

\section{G. Peran Pesantren Sidogiri Dalam membentuk Kemandirian Ekonomi Masyarakat}

Pondok Pesantren (Ponpes) Sidogiri merupakan salah satu pesantren tertua di Jawa Timur yang telah berusia ratusan tahun. Berdasarkan manuskrip yang ditulis KA. Sa'doellah Nawawie pada 1971, 
disebutkan bahwa Ponpes Sidogiri berdiri sejak 1745. Tahun itulah yang kemudian dijadikan sebagai tonggak peringatan hari lahirnya Ponpes Sidogiri.

Aktivitas pesantren ini bermula dari pendidikan ma'hadiyah. Pada 1938 didirikan pendidikan madrasiyah dengan nama Madrasah Miftahul Ulum dengan tingkat kelas sifir (nol) dan ibtidaiyah lalu dilanjutkan dengan dibukanya tingkat tsanawiyah pada 1957 dan aliyah pada 1983. Pendidikan ma'hadiyah adalah pendidikan asli pesantren yang sampai saat ini terus dipertahankan. Dengan pendidikan ma'hadiyah itulah, maka kader-kader muslim bermunculan yang arahnya mewujudkan manusia yang akan masuk dalam khairu ummah (umat yang terbaik).

Pendidikan madrasiyah atau klasikal terdiri atas pendidikan ibtidaiyah, tsanawiyah dan aliyah. Sedangkan pendidikan ma'hadiyyah lebih banyak mengarah kepada aktivitas pendidikan tambahan dan pelatihan kepada santri agar kelak bisa menjadi khairu ummah (sebaik-baik ummah) yang mengedepankan akhlakul karimah dalam setiap aktivitasnya. Dan masih banyak aktivitas lainnya yang akan menambah keterampilan (skill) para santri yang kelak akan berguna setelah kembali ke masyarakat.

Ponpes Sidogiri juga melatih para santri untuk menangani bidang perekonomian. Untuk itu, sejak 1961 KA. Sa'doellah Nawawie (Penanggung Jawab dan Ketua Pengurus Ponpes Sidogiri), merintis berdirinya koperasi sebagai wadah untuk belajar kemandirian, wirausaha (enterpreneurship) dan pengabdian bagi para santri. Kegiatan usaha 
pertamanya adalah membuka kedai dan warung kelontong di dalam lingkungan pesantren yang menyediakan kebutuhan sehari-hari para santri.

Sejak saat itulah, Koperasi Pondok Pesantren Sidogiri yang disingkat "Kopontren Sidogiri" terus melangkah dan tidak pernah berhenti dari aktivitasnya sampai sekarang ini. Bahkan mendapat predikat sebagai "Pesantren Wirausaha Pertama" (Republika, 1 November 2002). Meski Kopontren Sidogiri berdiri sejak 1961, namun berbadan hukum mulai 15 Juli 1997 dengan nomor 441/BH/KWK.13/VII/1997.

Saat ini Kopontren Sidogiri telah memiliki 68 cabang di beberapa wilayah di Jawa Timur seperti Pasuruan, Madura, Probolinggo, Bondowoso dan banyuwangi. Ke depan Kopontren Sidogiri akan terus berupaya untuk terus melakukan inovasi dan menjadi yang terdepan dalam bisnis ritel. Sejak 2013 Kopontren Sidogiri membentuk infrastruktur brand "BASMALAH" dengan nama "TOKO BASMALAH" dengan motto "Tempat Belanja yang Baik". Dari 68 cabang yang sudah dimiliki Kopontren Sidogiri, ada 22 cabang yang sudah menggunakan brand "BASMALAH". 22

\section{Kebangkitan Ekonomi Syariah}

Keberadaan Kopontren Sidogiri itulah yang kemudian hari menjadi cikal bakal kebangkitan ekonomi syariah di Sidogiri. Setelah berhasil mengembangkan Kopontren, pada pertengahan 1997 pengurus

\footnotetext{
${ }^{22}$ http://www.bmtugtsidogiri.co.id/berita-130.html.
} 
Volume 01 Nomor 01, Desember 2017

Kopontren dan beberapa orang guru Madrasah Miftahul Ulum (MMU) Ponpes Sidogiri memprakarsai berdirinya koperasi serba usaha yang fokus usahanya adalah simpan-pinjam pola syariah (SPS) dengan nama Koperasi Baitul Mal wa Tamwil Maslahah Mursalal lil Ummah disingkat menjadi Koperasi BMT MMU Sidogiri.

Mereka mendirikan Koperasi BMT MMU Sidogiri karena resah dengan kondisi masyarakat yang mulai terjerat dengan praktik ekonomi ribawi dalam bentuk rentener yang sudah merambah sampai ke desadesa di sekitar Sidogiri. Meski para pengelolanya-khususnya guruguru MMU yang biasanya berkutat dengan pelajaran kitab kuningmerasa seakan-akan memasuki dunia lain ketika menangani bisnis syariah, namun mereka berhasil mengembangkan Koperasi BMT MMU (Republika, 17 Maret 2004).

Sejak didirikan 1997, Koperasi BMT MMU menunjukkan kemajuan yang signifikan baik dari segi aktiva (aset), penerimaan kas (omzet) dan laba bersihnya (SHU). Unit pelayanannya tersebar di berbagai tempat di Jawa Timur. Sejak 25 September 2009 Koperasi BMT MMU Sidogiri telah diubah wilayah keanggotaannya menjadi lingkup provinsi Jawa Timur. Dengan demikian, alih binanya pun juga diubah yang semula Koperasi BMT MMU Sidogiri di bawah binaan Dinas Koperasi \& UMKM Kabupaten Pasuruan menjadi binaan Dinas Koperasi \& UMKM Provinsi Jawa Timur dengan SK perubahan Anggaran Dasar (SK PAD) No. 518.I/PAD/BH/XVI/66/103/2009. 
Selain itu, sejak 2013 Koperasi BMT MMU Sidogiri berganti nama menjadi Koperasi BMT Maslahah.

Setelah sukses mengembangkan Koperasi BMT MMU Sidogiri di kabupaten Pasuruan, para pengurusnya memprakarsai berdirinya Koperasi Usaha Gabungan Terpadu (UGT) Sidogiri. Pada 6 Juni 2000 mereka mendirikan Koperasi UGT Sidogiri di Surabaya yang kemudian menjadi cabang pertamanya. Koperasi UGT Sidogiri yang mereka dirikan, jumlah aset, omzet dan laba bersihnya terus tumbuh dan berkembang pesat serta makin mendapat kepercayaan dari masyarakat. Kini, Koperasi UGT telah memilik 227 unit pelayanan yang tersebar di Jawa Timur, Jawa Barat, Jakarta Utara dan luar Jawa.

Meski mulai berdiri terpaut tiga tahun lebih muda dari Koperasi BMT MMU Sidogiri, Koperasi BMT UGT Sidogiri berkembang melesat dan menjadi BMT yang memiliki aset terbesar di Indonesia. Berdasarkan urutan 10 BMT terbesar versi majalah Investor edisi September 2010, Koperasi BMT UGT Sidogiri menduduki tingkat pertama dengan aset sebesar Rp 153.718.513.449. Sedang Koperasi BMT MMU Sidogiri menduduki tingkat ketiga dengan aset sebesar Rp 56.789.856.176. Peringkat kedua diduduki oleh BMT Bina Ummat Sejahtera dari Jawa Tengah dengan aset sebesar Rp 130.075.119.276. 
Volume 01 Nomor 01, Desember 2017

10 BMT Terbesar versi majalah Investor edisi September 2010.

\begin{tabular}{|r|l|r|c|}
\hline No & Nama BMT & Aset (Rp) & Lokasi \\
\hline 1 & Usaha Gabungan Terpadu & 153.718 .513 .449 & Jawa Timur \\
\hline 2 & Bina Ummat Sejahtera & 130.075 .119 .276 & Jawa Tengah \\
\hline 3 & Maslahah Mursalal lil Ummah & 56.789 .856 .176 & Jawa Timur \\
\hline 4 & Tumang & 19.639 .395 .293 & Jawa Tengah \\
\hline 5 & Al-Huda & 15.805 .114 .168 & Jawa Tengah \\
\hline 6 & Usaha Artha Sejahtera & 15.205 .459 .602 & Jawa Tengah \\
\hline 7 & Fajar Mulia & 14.257 .742 .000 & Jawa Tengah \\
\hline 8 & Baskara Muhammadiyah & 13.708 .504 .919 & Lampung \\
\hline 9 & Fajar Metro & 11.876 .006 .130 & Lampung \\
\hline 10 & Duta Jaya & 10.664 .172 .724 & Lampung \\
\hline & Total Aset 10 BMT & 441.739 .883 .737 & \\
\hline
\end{tabular}

\section{Kemaslahatan untuk Umat}

Seiring dengan makin pesatnya pertumbuhan ketiga koperasi yang ada dalam lingkungan Pondok Pesantren Sidogiri tersebut, maka kemaslahatannya bagi umat juga semakin besar. Zakat yang dikeluarkan oleh ketiga koperasi tersebut telah mencapai lebih dari Rp 1 miliar. "Koperasi milik kami juga semakin berkembang setiap tahunnya. Untuk pengeluaran zakat saja di tahun ini kami mengeluarkan sekitar Rp 1 miliar dari tiga koperasi," papar Mahmud Ali Zein (Harian Radar Bromo, 14 Februari 2010).

Untuk mengoptimalkan pengelolaan dana zakat yang dikeluarkan oleh tiga koperasi di Sidogiri itu, mereka bekerjasama dengan Laziswa Sidogiri. Koperasi BMT UGT Sidogiri misalnya. Pada tahun buku 2011 yang lalu, bekerjasama dengan Lazizwa Sidogiri untuk menyalurkan 
dana zakat sebesar Rp 1,7 miliar. Pendistribusian dana zakat tersebut adalah sebagai berikut: zakat konsumtif, zakat produktif dan beasiswa.

Pertumbuhan zakat dan dana sosial setiap tahunnya meningkat tajam. Pada RAT Tahun Buku 2012 zakat dan dana sosial yang dikeluarkan oleh Kopontren Sidogiri, Koperasi BMT MMU Sidogiri dan Koperasi BMT UGT Sidogiri saja telah menembus angka Rp 10.198.162.234.

Laporan Zakat dan Dana Sosial RAT Tahun Buku 2012

\begin{tabular}{|l|r|r|r|}
\hline \multicolumn{1}{|c|}{ NAMA KOPERASI } & \multicolumn{1}{|c|}{ ZAKAT } & DANA SOSIAL & \multicolumn{1}{|c|}{ JUMLAH } \\
\hline Kopontren Sidogiri & 151.773 .789 & 55.692 .354 & 207.466 .143 \\
\hline Koperasi BMT MMU Sidogiri & 869.434 .471 & 1.477 .960 .644 & 2.347 .395 .115 \\
\hline Koperasi BMT UGT Sidogiri & 2.733 .619 .530 & 4.909 .681 .446 & 7.643 .300 .976 \\
\hline Total & & & $\mathbf{1 0 . 1 9 8 . 1 6 2 . 2 3 4}$ \\
\hline
\end{tabular}

Sumber: RAT Tahun Buku 2012 Kopontren Sidogiri, Koperasi BMT MMU

Sidogiri dan Koperasi BMT UGT Sidogiri.

\section{H. ANALISIS}

Pesantren Sidogiri adalah termasuk pesantren komperhensif yakni gabungan tradisional dan modern yang didalamnya tetap mengajarkan kitab kuning dengan metode sorogan dan mengembangkan sistem sekolah konvensional sampai perguruan tinggi (Sekolah Tinggi Agama Islam Sidogiri) lebih dari itu Pesantren Sidogiri mengembangkan sistem 
pendidikan dan pelatihan alternatif yakni melatih santri dan alumninya dalam pengembangan ekonomi dan pemberdayaan ekonomi masyarakat sekitar pesantren secara syariah dan sudah termanajemen dalam sebuah lembaga koperasi berupa BMT,UGT, LKAF, supermarket Basmalah dan lain sebagainya.

Dengan adanya pengembangan ekonomi dan pemberdayaan ekonomi masyarakat secara syariah Islam tersebut mampu membawa masyarakat sekitar pesantren Sidogiri menjadi harmonis antara individu dan sosial, makmur, sejahtera, adil, solidaritas dan distribusi pendapatan dan kekayaan yang merata. Artinya peran Pesantren Sidogiri disini sudah mampu menciptakan masyarakat dan santri sekaligus alumninya menjadi Islamic man ('ibadurrahman) sekaligus human Capital yang tangguh ditengah-tengah konsep kapitalis yang memperkeruh dunia dengan kegagalannya dalam memakmurkan, mensejahterakan, memerangi kemiskinan pada masyarakat. Kapitalis yang selalu menciptakan peperangan, penindasan dan perampasan hak milik orang lain. Artinya tidak ada harmonisan antara individu sebagai pemilik modal dan pekerja serta sosial masyarakat.

Kehadiran pesantrren Sidogiri yang mempraktekkan ekonomi Islam dalam pengembangan dan pemberdayaan ekonomi mampu menumbangkan konsep kapitalisnya Marx Weber yang memberikan konsep bahwa terdapat dukungan atau dalil agama kristen terhadap spirit adanya ekonomi kapitalis. Sayang ekonomi kapitalis tersebut gagal mensejahterakan masyarakat dan tidak adil. Berbeda dengan ekonomi Islam yang benar-benar diterapkan pesantren Sidogiri guna 
mengharmoniskan konflik antara kepentinan individu dan masyarakat terbukti adanya zakat, infaq, sodakoh, wakaf yang di atur oleh lembaga wakaf (Lkaf)Sidogiri. Dengan demikian pesantren Sidogiri mampu mengakhiri bentuk kekerasan dan akses negatif lain dari globalisasi. Globalisasi adalah neokoloniasme yang membawa gerbong kapitalis sebagai mana Giddens sebut sebagai Juggernut yang hilang kendali.

Pesantren Sidogiri adalah lembaga civil Societiyang mampu menjaga kemandirian pada negara dan bantuan asing, menyesuaikan diri dengan melakukan perubahan lewat detradisionalisasi tanpa meninggalka tradisi lama. Pesantren Sidogiri mampu menghindari budaya pop culture yang mewabah akibat globalisasi. Secara ekonomi pesantren Sidogiri mampu menjaga kemandirian ekonomi baik pada negara atau tergantung bantuan asing dengan melalukan inovasi dan terobosan dalam sistem pembelajaran dab segi manajemen yang modern.

\section{Kesimpulan}

Ekonomi kapitalis yang mendapatkan dukungan dari agama kristen ternyata gagal dalam mensejahterakan masyarakat dan tidak adil serta menindas kaum lemah yang digagas oleh Marx Weber. Sedangkan ekonomi Islam yang dilaksanakan oleh Pesantren Sidogiri dalam mengembangkan dan pemberdayaan ekonomi ternyata mampu membawa kesejahterakan masyarakat sekitar pesantren dengan cara wakaf, zakat, sodakoh, dan infak yang terhimpun dalam Lkaf. Peran sidogiri selain mensejahterakan, dan mengentas kemiskinan masyarakat sekitar pesantren tapi juga membantu jalannya pendidkan dengan mendanai madarasah- 
madrasah yang kurang mampu. Atinya kesusksesan Pesantren sidogiri ini telah meruntuhkan teori Marx Weber dan mungkin jikalau masih hidup Marx Weber wajib mondok dan nyantri di Pesantren Sidogiri ini. 
Volume 01 Nomor 01, Desember 2017

\section{DAFTAR PUSTAKA}

Prasojo, Sudjoko dkk, "laporan Hasil Penelitian Pesantren al-Falak dan Delapan Pesantren lain di Bogor", Jakarta: 1997.

Mastuhu, Dinamika Sistem Pendidikan Pesantren ,Jakarta: INIS, 1994.

Dhofier, Zamakhsyari. Tradisi Pesantren; Studi Tentang Pandangan Hidup Kiai, Jakarta: LP3ES, 1982.

Raharjo, M Dawam. Dunia Pesantren dalam...

Arifin, HM. Kapita Selekta Pendidikan, Jakarta: Bumi Aksara:1991.

Ghazali, M. Bahri. "Pesantren Berwawasan Lingkungan”, Jakarta: Prasasti, 2003.

10 Pesantren Terbaik Di Indonesia - qolbunhadi.html.

Chamid, Nur. Jejak Langkah Sejarah Pemikiran Ekonomi Islam, Yogyakarta : Pustaka Pelajar : 2010.

Chapra, M Umer. Masa Depan Ilmu Ekonomi, Jakarta: Gema Insani Press, 2001

Nasyith Majidi, dan Awalil Rizki. Neo Liberalisme Mencengkram Indonesa

Chapra, M. Umer. Islam dan Tantangan Ekonomi, Jakarta: Gema Insani Press, 2000

Husein At-tariqi, Abdullah A. Ekonomi Islam, Prinsip, dasar dan Tujun, Yogyakarta: MIP, 2004.

Mawawi, Ismail. Ekonomi Islam : Perspektif Teori, Sistem, dan Aspek Hukum, Surabaya: CV. Putra Media Nusantara, 2009. 
Mawawi, Heri, Konsep Ekonomi Islam : Suatu Pengantar, Yogyakarta, Ekonisia, 2004.

Nurcholis, "Perbedaan Mendasar Ekonomi Islam dan Ekonomi Konvensional",dalam Menjawab Keraguan dalam Berekonomi Syari'ah, Yogyakarta: Safira Insania Press, 2008.

Karim, M. Rusli. Berbagai Aspek Ekonomi Islam, Yogyakarta , PT. Tiara Wacana, 1992.

Sudarsono, Heri. Konsep Ekonomi Islam : Suatu Pengantar.

http://www.paltangerangkota.go.id/index.php?option=com_content\&view=art icle\&id=288:menelusuri-sistem-ekonomi-islam-dan-sistem-ekonomikapitalis-sebuah-tinjauan-singkat\&catid=3:artikelmakalah\&Itemid=49, 22 mei 2012.

http://www.bmtugtsidogiri.co.id/berita-130.html. 